\title{
Cronkhite-Canada Syndrome: A Case Report and Literature Review of Gastrointestinal Polyposis Syndrome
}

\author{
Xinying Shen', Michael Husson'2, William Lipshutz1 \\ ${ }^{1}$ Penn Gastroenterology at Pennsylvania Hospital, Philadelphia, USA \\ ${ }^{2}$ Department of Pathology \& Laboratory Medicine, Pennsylvania Hospital, Philadelphia, USA \\ Email: xinyings@yahoo.com, william.lipshutz@uphs.upenn.edu
}

Received 6 November 2014; revised 1 December 2014; accepted 16 December 2014

Copyright (C) 2014 by authors and Scientific Research Publishing Inc.

This work is licensed under the Creative Commons Attribution International License (CC BY).

http://creativecommons.org/licenses/by/4.0/

c) (i) Open Access

\section{Abstract}

Cronkhite-Canada syndrome (CCS) is a rare, non-inherited polyposis syndrome, characterized by diffuse gastrointestinal (GI) hamartomatous polyposis with unique dermatologic changes including alopecia, skin hyperpigmentation, and nail dystrophy. Patients can typically present with diarrhea, weight loss, protein-losing enteropathy, and nutritional deficiency. However, it can demonstrate diverse other clinical features, usually with poor prognosis. Currently, there are no specific diagnostic criteria established yet. The etiology of CCS is still obscure, but an autoimmune process has been suggested. Here we present an 81-year-old Caucasian female who had clinical presentations, physical exam, imaging, endoscopy and pathology findings that were all consistent with the diagnosis of CCS. We also include a detailed literature review of the other gastrointestinal polyposis syndromes (hamartomatous, adenomatous, hyperplastic and inflammatory polyposis). A high index of suspicion and recognition of the characteristic clinical, endoscopic as well as histopathological findings of CCS, as well as different gastrointestinal polyposis conditions, can help clinicians with more timely and correct diagnosis.

\section{Keywords}

Cronkhite-Canada Syndrome, Intestinal Polyposis, Adenomatous Polyposis, Hamartomatous Polyposis, Hyperplastic Polyposis, Inflammatory Polyposis

\section{Introduction}

The Cronkhite-Canada syndrome (CCS) was a rare, non-hereditary disorder that was originally described in

How to cite this paper: Shen, X.Y., Husson, M. and Lipshutz, W. (2014) Cronkhite-Canada Syndrome: A Case Report and Literature Review of Gastrointestinal Polyposis Syndrome. Case Reports in Clinical Medicine, 3, 650-659. 
1955 by Leonard W. Cronkhite, and Wilma J. Canada [1]. The syndrome is characterized by diffuse gastrointestinal (GI) hamartomatous polyps, a unique dermatologic triad of alopecia, skin hyperpigmentation, and onychodystrophy, along with clinical features of diarrhea, weight loss, protein-losing enteropathy, and malabsorptive syndrome.

\section{Case}

An 81-year-old Caucasian female with past medical history of hypothyroidism (currently on synthroid) and colon adenocarcinoma status post right hemicolectomy (2006), presented to the GI office with new onset diarrhea and weight loss of 16 lbs over one month. The diarrhea was profuse, 7 - 8 watery stools every day, sometimes associated with fecal incontinence, but without blood, mucus, or abdominal pain. She also had loss of appetite and pruritic rash on the inner thighs. She initially went to ER for the diarrhea, but was found to have pneumonia and treated with levaquin. Her diarrhea continued. Her family history was significant for colon adenocarcinoma, affecting her father, maternal uncle, and two cousins. She lived alone, and denied alcohol, tobacco or illicit drug use. Her physical examination showed rashes on inner thighs, mild bilateral lower extremity edema, and guaiac positive brown stool.

Her blood work showed normal hemoglobin concentration with elevated MCV (107 fL), deceased serum potassium (K), total protein and albumin (K $3.1 \mathrm{mmol} / \mathrm{L}$, serum albumin $2.4 \mathrm{~g} / \mathrm{dL}$, total protein $4.7 \mathrm{~g} / \mathrm{dL}$ ). Her other serum electrolytes, liver function tests (liver enzymes [ALT, AST], total bilirubin, and alkaline phosphatase), and 24-hr urine protein were all normal. Her vitamin B12 was low $(128 \mathrm{pg} / \mathrm{mL})$, TSH was elevated $(8.65$ $\mathrm{uIU} / \mathrm{mL})$. Her CEA was $5.3 \mathrm{ng} / \mathrm{mL}(\mathrm{nl}<5)$. Stool cultures, stool clostridium difficile toxin and celiac panel were all negative.

Computed tomography (CT) of the abdomen and pelvis showed gastric fold thickening, most prominent in the distal gastric body and gastric antrum (Figure 1). She underwent an esophagogastroduodenoscopy (EGD) which revealed prominent gastric folds in the entire stomach, with diffuse edematous mucosa and nodular swelling (Figure 2). Biopsy showed benign hyperplastic/inflammatory polypoid gastric mucosa with focal glandular dilation, and lamina propria expansion (Figure 3). H. pylori staining of the biopsy was positive.

She showed mild improvement after $\mathrm{H}$. Pylori eradication treatment, and was started on B12 supplements. However, her diarrhea recurred again, resulting in a total of $25 \mathrm{lb}$ weight loss, with hair thinning, loss of fingernails, and hyperpigmentation of the skin (Figure 4). Colonoscopy was performed, and showed similar features of edematous, nodular-appearing colonic mucosa (Figure 5). Biopsy reported colonic mucosa with glandular dilation, edema, congestion, chronic inflammation, with focal epithelial inflammatory atypia noted (Figure 6).

She subsequently had an upper GI with small bowel follow through (SBFT), which revealed diffusely thickened and nodular gastric folds and evidence of innumerable tiny nodules or polyps, particularly in the antrum with mild distal small bowel fold thickening (Figure 7). A diagnosis of Cronkhite-Canada syndrome (CCS) was made, and she was started on treatment with proton pump inhibitor (dexlansoprazole $30 \mathrm{mg}$ once daily), medium chain triglyceride diet with ensure plus protein supplements, and steroid (prednisone $40 \mathrm{mg}$

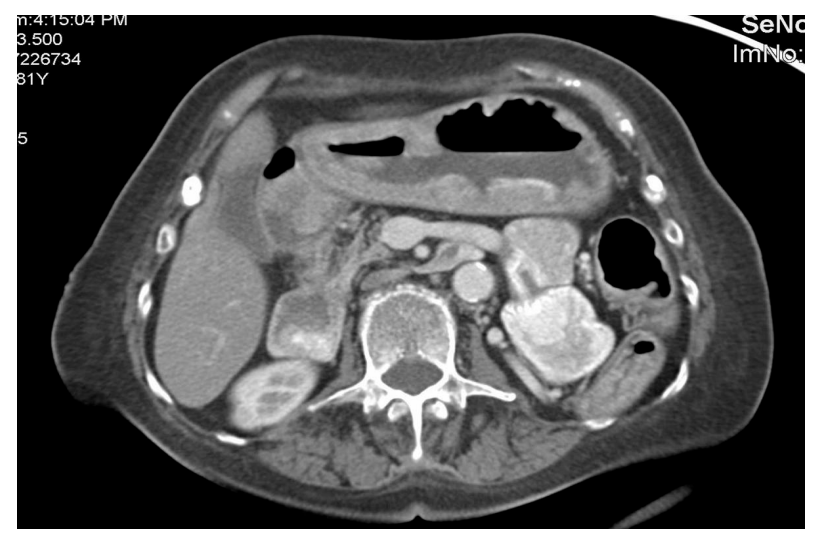

Figure 1. Computed tomography showed gastric fold thickening, most prominent in distal body and antrum. 


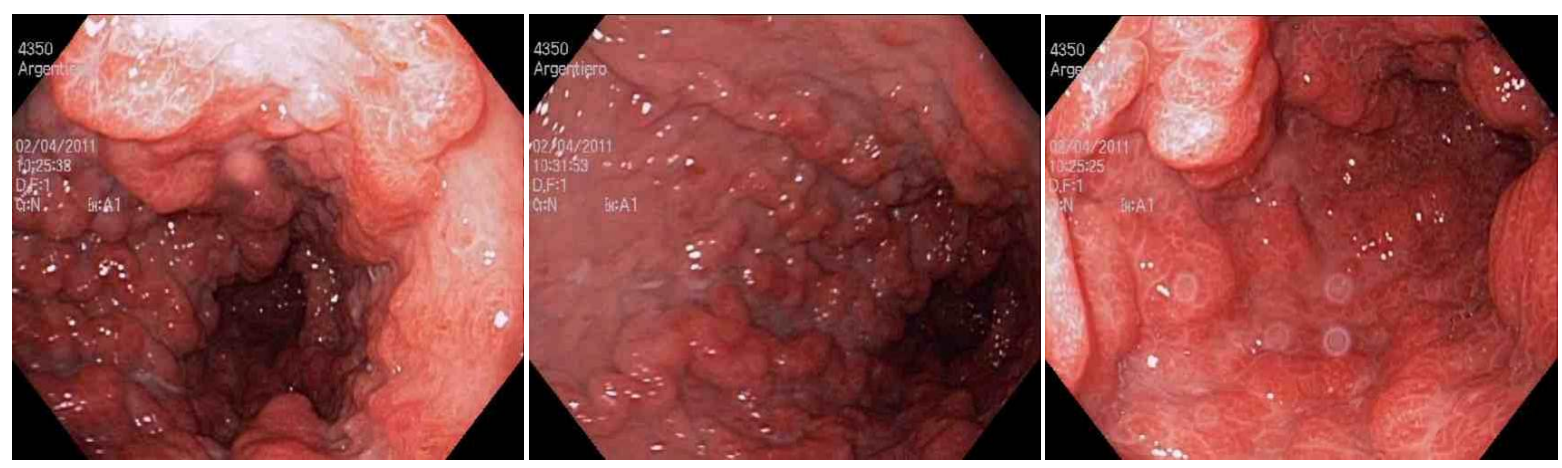

Figure 2. EGD with diffuse nodular swelling and edema of gastric mucosa.
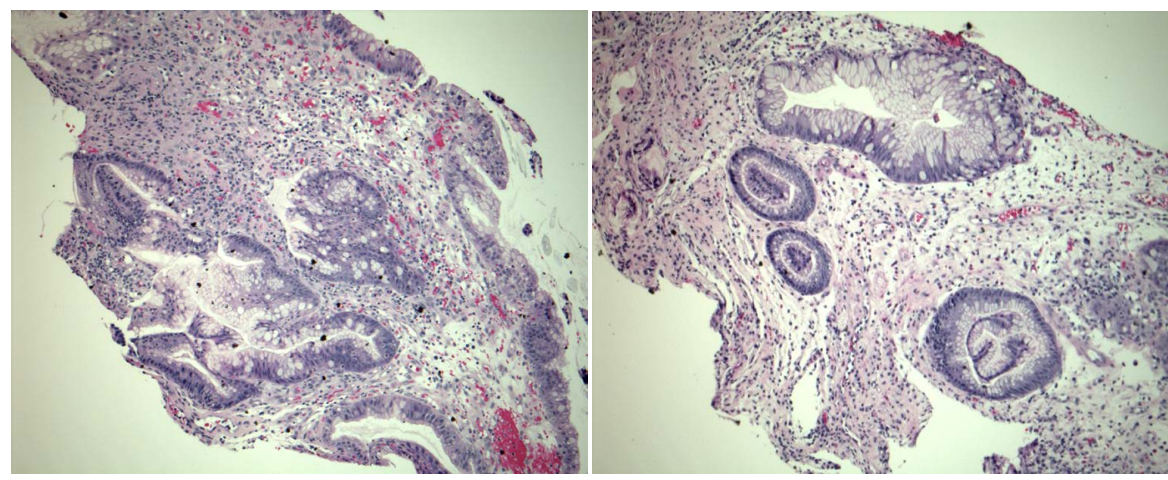

Figure 3. EGD Biopsy—polypoid gastric mucosa, proliferative and tortuous gastric pits with cystically dilated glands which are widely separated by inflammatory and edematous stroma.
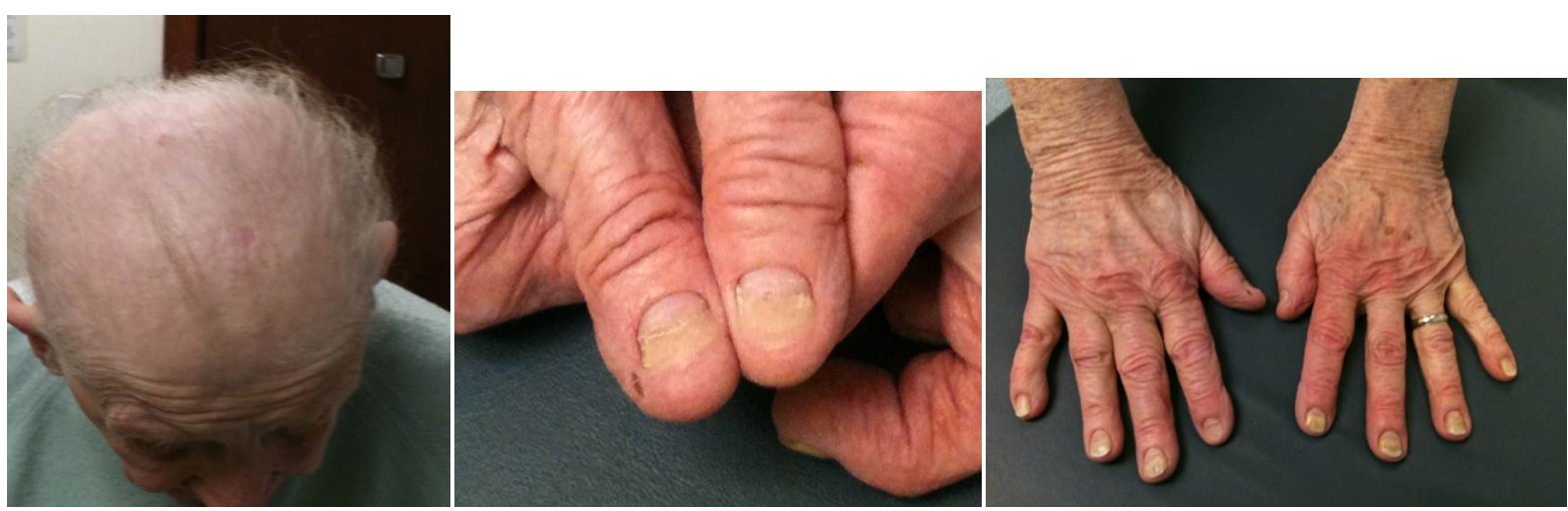

Figure 4. Unique ectodermal changes: hair thinning and onychodystrophy (thinning, splitting, spongy and ragged fingernails).

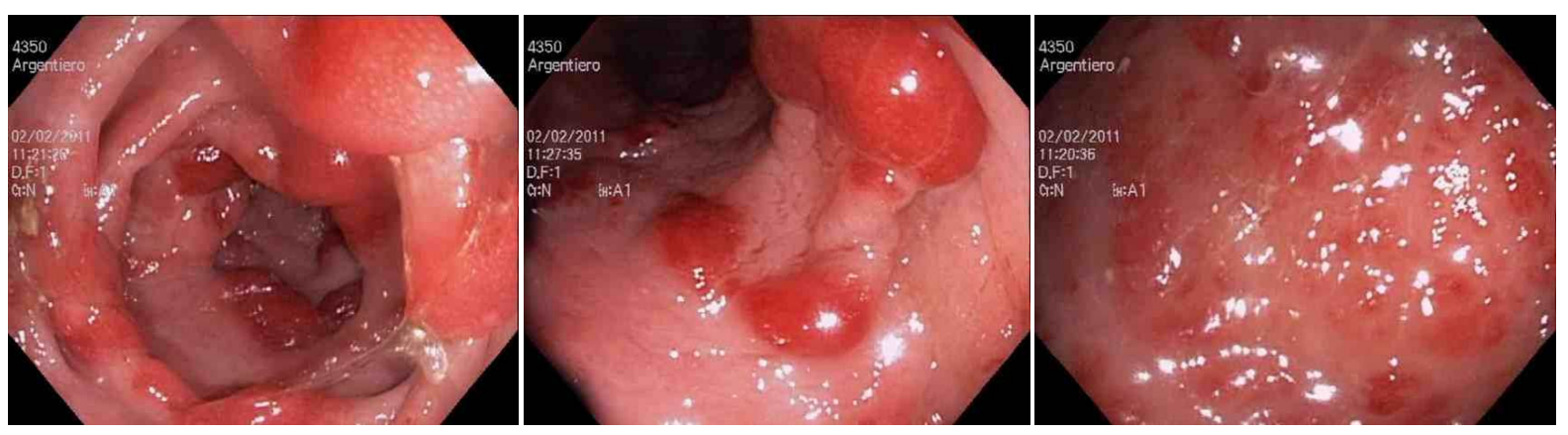

Figure 5. Colonoscopy showed erythematous, inflamed and nodular-appearing colonic mucosa. 

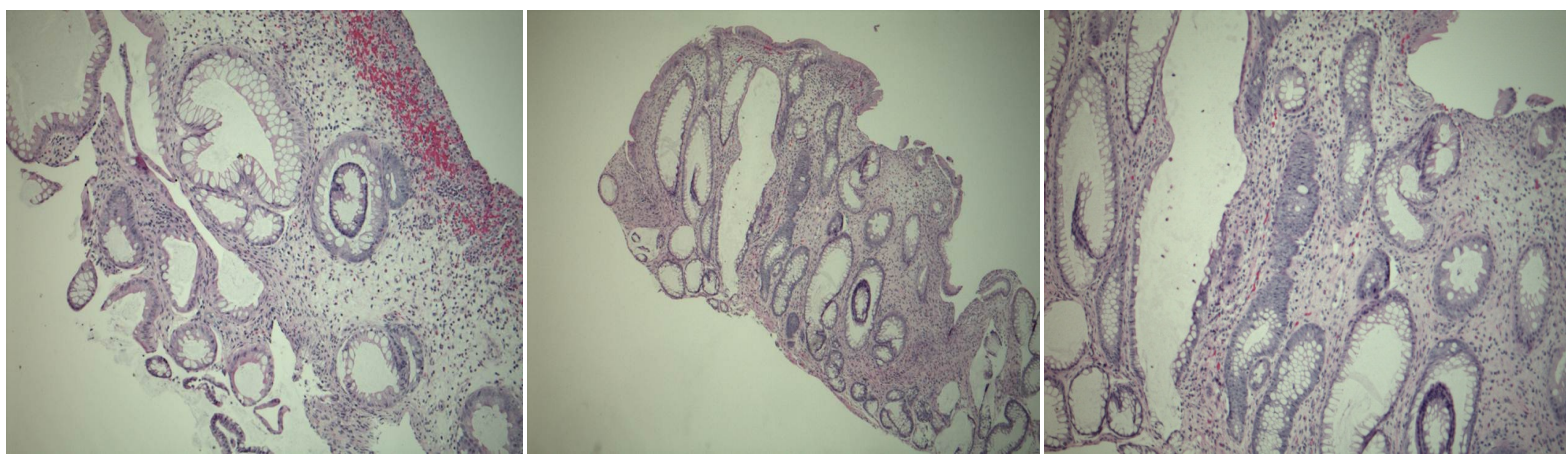

Figure 6. Colon Biopsy-Glandular hyperplastic change, distorted and focally distended crypts, edema, congestion and increased lymphoplasmacytic and neutrophilic infiltrates in the lamina propria. Epithelial inflammatory atypia is noted focally.

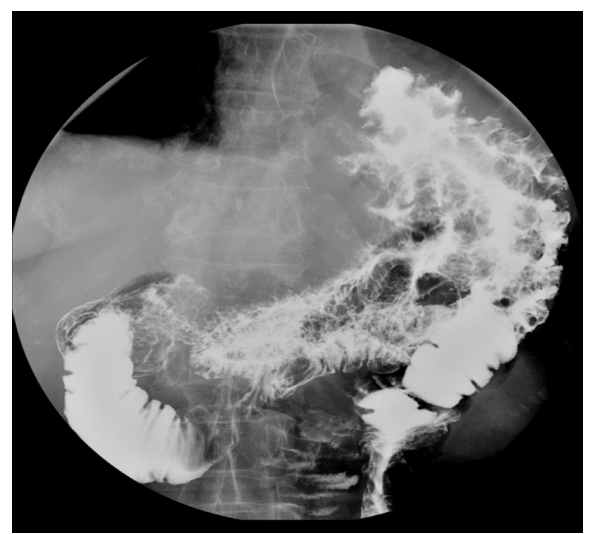

Figure 7. Upper GI with SBFT-diffusely thickened and nodular gastric fold, particularly in the fundus and body; innumerable tiny nodules or polyps, particularly in the antrum.

once daily, tapered by $5 \mathrm{mg}$ every 2 weeks). She was also given low dose Lasix for her peripheral edema, with potassium supplements.

\section{Discussion}

The Cronkhite-Canada syndrome (CCS) is an uncommon, non-hereditary GI hamartomatous polyposis syndrome. Since its first description in 1955, there have been more than 500 cases reported in the literature. So far no germline mutation has been found, and there does not appear to have familial predisposition. It occurs most often in middle-aged or older adults, with a slight male predominance of male-to-female ratio of 3:2 [2]. European and Asian patients appear to be most frequently affected [3], with 75\% of cases being reported in Japan [4].

The etiopathogenesis of CCS is still unclear. In the past, mental and physical stresses were reported as precipitating factors [4]. Recently, however, there has been increasing evidence of autoimmune mechanism being involved in the process. For example, it was reported that positive immune staining for IgG4 plasma cells are increased in the CCS polyps [5] [6]. There has been associations between CCS and elevated antinuclear antibodies (ANA), as well as some autoimmune diseases (systemic lupus erythematous, membranous glomerulonephritis, rheumatoid arthritis, hypothyroidism, or scleroderma, etc.) [7] [8]. Treatment responses to corticosteroids or azathioprine also suggest possible underlying autoimmune mechanism. $H$. pylori infection was also reported to be related, and eradication of $H$. pylori seems to improve symptoms in some cases [9] [10].

Patients typically present with diarrhea, weight loss, hematochezia, or abdominal pain. The diarrhea is usually 5 - 7 bowel movements a day, and the volume can be as high as 4 - 6 L/day. Hypogeusia or dysgeusia, progressive anorexia, xerostomia, or neurologic symptoms (such as seizures) has also been reported [3], although our patient did not have these symptoms.

The unique ectodermal abnormalities of CCS include alopecia, onychodystrophy and diffuse skin hyperpigmentation. Alopecia can involve scalp, eyebrows, axillae, pubic areas, and extremities, and eventually complete 
hair loss in some patients. Onychodystrophic changes include thinning, splitting, spongy change, onycholysis (partial separation of nail from bed), and onychomadesis (loss of fingernails and toenails). The skin hyperpigmentation is usually manifested in the form of brown macules and plaques on the dorsal surface of the hands, palms, face, neck, and soles. This special dermatological triad is an important feature to distinguish CCS from the other hamartomatous polyposis syndromes (see below).

Radiographically or endoscopically, multiple hamartomatous polyps (varies from 5 to innumerable) are diffusely distributed throughout the GI tract, only sparing the esophagus. Histologically, they can be indistinguishable from juvenile polyposis, characterized by cystic gland dilatation, expanded edematous lamina propria, hyperplasia of foveolar epithelium and mild infiltration of inflammatory cells including eosinophils. Most of the polyps in CCS are non-neoplastic, however, it has been reports that serrated adenomas and carcinomas can arise from the CCS polyps, mostly gastric or colonic (sigmoid or rectum more common) [11]-[14]. Due to the rarity of the disease, optimal screening protocol has not been developed, although endoscopic surveillance is suggested.

Our patient presented in the paper had both upper and lower GI polyposis. Her physical examination, endoscopic findings, pathological features, and anatomic distribution of her polyps are all typical for CCS.

The disease course is usually progressive, leading to anemia, electrolyte disturbances, hypoalbuminemia, hypoproteinemia and vitamin deficiencies due to malabsorption and GI losses. The 5-year mortality rate of CCS has been reported to be 55\% [4]. Complications of the polyposis can include gastrointestinal bleeding, intussusception and rectal prolapse. However, there have been reported long-term survivors and spontaneous remissions.

The optimal treatment of CCS has not been established because of the rarity of the disorder and the poor understanding of the etiology. Current literature favors a combination therapy including nutritional support, H2 receptor antagonist or proton pump inhibitors (PPIs), immune suppression (corticosteroids, azathioprine and cyclosporine), antibiotics, cromolyn sodium, or surgery [15]. Nutritional therapy and corticosteroids are currently recommended as the mainstay of treatment. Our patient was treated with medium chain triglyceride diet with ensure plus protein supplements, dexlansoprazole, and prednisone.

\section{Differential Diagnosis}

The differential diagnosis includes a number of gastrointestinal polyposis syndromes (Table 1), which can be classified into 4 groups based on the polyp type: hamartomatous, adenomatous, hyperplastic, and inflammatory. These are distinguished based on the polyp histology, polyp distribution, clinical presentations, family history, and molecular genetic testing.

\subsection{Hamartomatous Polyposis Syndrome}

Hamartomatous polyps are overgrowth of the normal cellular tissue of the GI tract, but have a markedly distorted architecture. CCS, along with Juvenile polyposis syndrome (JPS), Peutz-Jeghers syndrome (PJS), and Cowden syndrome (CS) all belong to the hamartomatous polyposis family. Only CCS is sporadic and nonfamilial. The remaining hamartomatous polyposis syndromes are autosomal dominant, with their own specific germline mutation, clinical manifestations, as well as intestinal and extra-intestinal malignancy risks (Table 2).

\subsubsection{Juvenile Polyposis Syndrome (JPS)}

Juvenile polyposis syndrome is characterized by multiple juvenile polyps in the GI tract ( 5 is the minimal for diagnosis, but most cases have 50 - 200). It is typically diagnosed before the age of 20. It is autosomal dominant with 3 genes, SMAD4, BMPR1A, and ENG, being implicated. JPS polyps histologically most resemble CCS polyps. The JPS polyps are pedunculated, demonstrating a villiform architecture. Histologically, the polyp demonstrates edematous lamina propria, with gland dilatation and inflammatory cell infiltration [20] [21]. Polyps predominantly occur in the colon and rectum. The chance of polyps in the stomach and small intestine is less than $20 \%$ [22]. There may be extra-intestinal anomalies, including macrocephaly, hydrocephalus, hypertelorism, cleft palate, polydactyly, Meckel's diverticulum, and intestinal malrotations [23]. JPS is associated with an increased risk of colorectal cancer. The cumulative lifetime risk can be as high as $40 \%-50 \%$ [24]. There are also reported cases of gastric cancer, small bowel carcinoma and pancreatic cancer associated with JPS [22].

\subsubsection{Peutz-Jeghers Syndrome (PJS)}

In addition to hamartomatous polyps being distributed throughout the GI tract, Peutz-Jeghers syndrome (PJS) 
Table 1. Colorectal polyposis syndrome [16]-[18].

\begin{tabular}{|c|c|c|c|c|c|c|}
\hline Disease & $\begin{array}{c}\text { Age of } \\
\text { onset }\end{array}$ & Gene & $\begin{array}{l}\text { Mode of } \\
\text { inheritance }\end{array}$ & \# Polyps & Polyps distribution & Histology \\
\hline \multicolumn{7}{|c|}{ Non-neoplastic polyps } \\
\hline $\begin{array}{l}\text { Inflammatory } \\
\text { “cap” polyposis }\end{array}$ & $40-50$ & - & Sporadic & 1 to $>100$ & $\begin{array}{l}\text { Predominantly in distal colon, but } \\
\text { can be throughout the colon }\end{array}$ & $\begin{array}{l}\text { Hyperplastic crypts, inflammatory } \\
\text { infiltrate and fibromuscular } \\
\text { obliteration of the lamina propria, with } \\
\text { a white cap of fibrinopurulent exudate }\end{array}$ \\
\hline $\begin{array}{l}\text { Hyperplastic } \\
\text { polyposis }\end{array}$ & $>40$ & - & $\begin{array}{c}\text { Familial } \\
\text { cluster }\end{array}$ & $\begin{array}{l}5-100 \\
\text { mostly } \\
40-100\end{array}$ & $\begin{array}{l}\text { Abundance throughout the colon, } \\
\text { sparing of stomach or small bowel }\end{array}$ & $\begin{array}{l}\text { Hyperplastic polyps, sessile serrated } \\
\text { adenomas }\end{array}$ \\
\hline \multicolumn{7}{|c|}{ Adenomatous polyposis } \\
\hline $\begin{array}{l}\text { Classical Familial } \\
\text { adenomatous } \\
\text { polyposis (FAP) }\end{array}$ & $10-20$ & $A P C$ & $\mathrm{AD}$ & $>100$ & $\begin{array}{l}\text { Colorectum (100\%), gastric fundic } \\
\text { gland polyps, duodenum, and } \\
\text { periampullary polyps }\end{array}$ & $\begin{array}{l}\text { Adenoma ( tubular adenomas identical } \\
\text { to sporadic adenomas) }\end{array}$ \\
\hline $\begin{array}{l}\text { Attenuated FAP } \\
\text { (AFAP) }\end{array}$ & $20-30$ & $A P C$ & $\mathrm{AD}$ & $<100$ & $\begin{array}{l}\text { Colorectum, Gastroduodenum } \\
\text { and periampullary polyps }\end{array}$ & Adenoma (same as FAP) \\
\hline $\begin{array}{c}\text { MUTYH- } \\
\text { associated } \\
\text { polyposis (MAP) }\end{array}$ & $40-60$ & MUTYH & $\mathrm{AR}$ & $20-100$ & $\begin{array}{l}\text { Colorectum } \\
\text { Gastric and duodenal polyps }\end{array}$ & $\begin{array}{l}\text { Adenoma (tubular adenomas, with a } \\
\text { minority of tubulovillous adenomas } \\
\text { and few hyperplastic polyps) }\end{array}$ \\
\hline \multicolumn{7}{|c|}{ Hamartomatous polyposis } \\
\hline $\begin{array}{l}\text { Juvenile } \\
\text { polyposis } \\
\text { syndrome }\end{array}$ & $<20$ & $\begin{array}{l}\text { SMAD4, } \\
\text { BMPR1A, } \\
\quad E N G\end{array}$ & $\mathrm{AD}$ & 5 to 200 & $\begin{array}{l}\text { More common in the colorectum. } \\
\text { The chance in the stomach and } \\
\text { small intestine are }<20 \%\end{array}$ & $\begin{array}{l}\text { Mucous-filled, edematous stroma, } \\
\text { dilated glands, inflammatory cell } \\
\text { infiltration, and absence of } \\
\text { smooth-muscle proliferation }\end{array}$ \\
\hline $\begin{array}{l}\text { Peutz-Jeghers } \\
\text { syndrome }\end{array}$ & $10-30$ & $\begin{array}{l}\text { STK11 } \\
\text { gene }\end{array}$ & $\mathrm{AD}$ & $1-20$ & $\begin{array}{l}\text { Most common in small intestine } \\
(100 \%), \text { less common in } \\
\text { colorectum and stomach ( } 20 \%) \text {. } \\
\text { Also seen extra-intestinal tract such } \\
\text { as respiratory, uterus, or bladder }\end{array}$ & $\begin{array}{l}\text { “Christmas tree” appearance at low } \\
\text { power, Hamartomatous polyps } \\
\text { supported by broad bands of } \\
\text { muscularis mucosa smooth muscle }\end{array}$ \\
\hline $\begin{array}{l}\text { Cowden } \\
\text { syndrome }\end{array}$ & $9-20$ & PTEN & $\mathrm{AD}$ & Multiple & Throughout the GI tract & $\begin{array}{l}\text { Hamartomatous polyps, histologically, } \\
\text { similar to the juvenile polyps, } \\
\text { frequently containing ganglion cells }\end{array}$ \\
\hline $\begin{array}{c}\text { Bannayan- } \\
\text { Ruvalcaba- } \\
\text { Riley syndrome }\end{array}$ & $\begin{array}{l}\text { Early in } \\
\text { life }\end{array}$ & PTEN & $\mathrm{AD}$ & Multiple & $\begin{array}{l}\text { Majority are identified in the distal } \\
\text { ileum and colon, though they may } \\
\text { be seen throughout the GI tract }\end{array}$ & $\begin{array}{l}\text { Hamartomatous polyps, histologically } \\
\text { similar to the JPS-type polyp }\end{array}$ \\
\hline $\begin{array}{l}\text { Cronkhite- } \\
\text { Canada } \\
\text { syndrome }\end{array}$ & $50-60$ & -- & Sporadic & $\begin{array}{l}5 \text { to } \\
\text { numerous }\end{array}$ & $\begin{array}{c}\text { Predominantly in stomach and } \\
\text { colon ( } 90 \%), \text { followed by small } \\
\text { bowel (80\%) and rectum (67\%), } \\
\text { usually spare esophagus }\end{array}$ & $\begin{array}{c}\text { Hamartomatous polps exhibiting } \\
\text { glandular hyperplasia, cystic dilation, } \\
\text { mucosal edema }\end{array}$ \\
\hline
\end{tabular}

AD: Autosomal Dominant; AR: Autosomal Recessive.

are also associated with distinctive mucocutaneous pigmented lesions (melanosis), most commonly on the lips and buccal mucosa, less frequently on the hands, feet, periorbital and genital area. These tend to fade during puberty [25]. PJS is autosomal dominant inherited, and caused by germline mutation in STK11 gene (located at chromosome 19p13.3). The onset of symptoms is usually the $2^{\text {nd }}$ or $3^{\text {rd }}$ decade of life. The polyps are most numerous in small intestine, with colorectum and stomach to a lesser extent, but also occur in extra-intestinal sites, such as upper and lower respiratory tract, uterus and bladder [21]. The polyps vary in size, have a papillary surface and resemble tubulovillous adenomas grossly [26]. Microscopically, PJS polyps demonstrate a characteristic arborizing pattern of extensive smooth-muscle proliferation, distinguishing them from juvenile polyps, which do not contain muscularis mucosa [23]. PJS is associated with an increased risk of both gastrointestinal (esophagus, gastric, small bowel, colorectum, pancreas) and non-gastrointestinal cancers (breast, lung, ovarian and testicular cancer). Female breast cancer risk is $45 \%$ - 54\% [25]. Female benign ovarian sex-cord tumours with annular tubules (SCTAT), cervical adenoma malignum, and male Sertoli-cell testicular tumors are some other tumors associated with PJS. 
Table 2. Extra-intestinal manifestations and malignancy risks of gastrointestinal polyposis [17] [19].

\begin{tabular}{|c|c|c|c|}
\hline Disease & Extra-colonic manifestations & $\begin{array}{l}\text { Lifetime CRC or GI } \\
\text { malignancy risks }\end{array}$ & Extra-gastrointestinal malignancy \\
\hline \multicolumn{4}{|c|}{ Non-neoplastic Polyps } \\
\hline $\begin{array}{l}\text { Inflammatory } \\
\text { “cap” polyposis }\end{array}$ & None & No & - \\
\hline $\begin{array}{l}\text { Hyperplastic } \\
\text { polyposis }\end{array}$ & None & $\begin{array}{l}\text { Increased risk of CRC (mostly } \\
\text { R-sided) }\end{array}$ & - \\
\hline \multicolumn{4}{|c|}{ Adenomatous polyposis } \\
\hline $\begin{array}{l}\text { Classical Familial } \\
\text { adenomatous } \\
\text { polyposis (FAP) }\end{array}$ & $\begin{array}{l}\text { Upper GI polyposis: gastric FGP, } \\
\text { duodenum and ampullary adenomas } \\
\text { /adenocarcinomas } \\
\text { - Desmoids tumors, osteomas, } \\
\text { epidermoid cysts, dental abnormalities, } \\
\text { CHRPE }\end{array}$ & $\begin{array}{c}\text { 100\% CRC (left-sided } \\
\text { predominance) } \\
\text { Duodenal and periampullary } \\
\text { cancer }(4 \%-12 \%)\end{array}$ & $\begin{array}{c}\text { Thyroid cancer }(1 \%-2 \%) \text {, } \\
\text { hepatoblastoma }(1 \%-2 \%) \text {, } \\
\text { medulloblastoma }(<1 \%)\end{array}$ \\
\hline $\begin{array}{l}\text { Attenuated FAP } \\
\text { (AFAP) }\end{array}$ & $\begin{array}{l}\text { Upper GI polyposis: gastric FGP, } \\
\text { duodenum and ampullary adenomas } \\
\text { /adenocarcinomas } \\
\text { - Usually lack the extra-intestinal } \\
\text { manifestations of classic FAP }\end{array}$ & $\begin{array}{l}80 \% \text { - } 100 \% \text { CRC (usually } \\
\text { right-sided) } \\
\text { Duodenal and periampullary } \\
\text { cancer }(4 \%-12 \%)\end{array}$ & Thyroid cancer (1\% - 2\%) \\
\hline $\begin{array}{l}\text { MUTYH- } \\
\text { associated } \\
\text { polyposis (MAP) }\end{array}$ & $\begin{array}{l}\text { - Gastric FGP, duodenal } \\
\text { adenomas/adenocarcinomas } \\
\text { - CHRPE, osteomas,and Muir-Torre } \\
\text { phenotype with sebaceous gland } \\
\text { tumors }\end{array}$ & $\begin{array}{l}\text { 80\% - } 100 \% \text { CRC } \\
\text { (2/3 right sided) } \\
\text { Duodenal cancer }(4 \%)\end{array}$ & $\begin{array}{l}\text { Increased risk of ovarian, bladder, } \\
\text { skin, and breast cancer }\end{array}$ \\
\hline \multicolumn{4}{|c|}{ Hamartomatous polyposis } \\
\hline $\begin{array}{l}\text { Juvenile polyposis } \\
\text { syndrome (JPS) }\end{array}$ & $\begin{array}{l}\text { - Pulmonary arterio-venous } \\
\text { malformations } \\
\text { - Mucocutaneous telangiectasias }\end{array}$ & $\begin{array}{l}\text { CRC (68\%), gastric ( } 21 \%) \text {, small } \\
\text { bowel, and pancreatic cancer }\end{array}$ & No increased risk in extra-GI site \\
\hline $\begin{array}{l}\text { Peutz-Jeghers } \\
\text { syndrome }\end{array}$ & $\begin{array}{l}\text { - Mucocutaneous melanosis (lips, } \\
\text { buccal mucosa) }\end{array}$ & $\begin{array}{c}\text { CRC (39\%), gastric (29\%), small } \\
\text { bowel (13\%), pancreatic cancer } \\
(36 \%)\end{array}$ & $\begin{array}{l}\text { Breast (54\%), lung (15\%), ovarianor } \\
\text { testicular cancer; ovarian sex-cord } \\
\text { tumors with annular tubules (SCTAT), } \\
\text { cervical adenoma malignum, male } \\
\text { Sertoli-cell testicular tumors }\end{array}$ \\
\hline $\begin{array}{l}\text { Cowden } \\
\text { syndrome }\end{array}$ & $\begin{array}{l}\text { Mucocutaneous lesions (facial } \\
\text { trichilemmomas, acral keratosis, } \\
\text { papillomatous papules), LDD, } \\
\text { macrocephaly, mental retardation } \\
\text { - Glycogenic acanthosis of the } \\
\text { esophagus }\end{array}$ & Low & $\begin{array}{l}\text { Breast (50\%), thyroid (10\%), } \\
\text { endometrial, ovarian or cervical cancer, } \\
\text { renal cell carcinoma, bladder } \\
\text { transitional carcinoma }\end{array}$ \\
\hline $\begin{array}{l}\text { Cronkhite-Canada } \\
\text { syndrome }\end{array}$ & $\begin{array}{l}\text { Unique dermatologic triad: alopecia, skin } \\
\text { hyperpigmentation, onychodystrophy }\end{array}$ & $\begin{array}{l}\text { CRC (mostly left sided) } \\
\text { Gastric cancer }\end{array}$ & - \\
\hline
\end{tabular}

CRC—Colorectal Cancer; GI—Gastrointestinal; FGP—Fundic Gland Polyps; CHRPE—Congenital Hypertrophy of the Retinal Pigment Epithelium; LDD—Lhermitte-Duclos Disease.

\subsubsection{Cowden Syndrome (CS) and Bannayan-Ruvalcaba-Riley Syndrome (BRRS)}

Both Cowden syndrome (CS) and Bannayan-Ruvalcaba-Riley syndrome (BRRS) are autosomal dominant disorders, caused by the germline mutations of the tumor suppressor gene PTEN (on chromosome 10q23). They are refered to as the PTEN hamartomatous tumor syndrome (PHTS). CS is characterized by multiple hamartomatous polyps throughout the GI tract. CS is associated with increased risk of breast, thyroid, and endometrial cancer, but not GI tract [27]. Histologically, the polyps differentiated from CCS polyps by their small size, dome-shaped appearance, minimal crypt dilation and frequently containing ganglion cells. The mucocutaneous lesions of CS are the most striking characteristics: facial trichilemmomas (benign tumors of the hair follicles), acral keratosis, oral cobblestoning, and papillomas. In addition, Lhermitte-Duclos disease (LDD), macrocephaly, mental retardation, benign lesions of the thyroid or breast, such as nontoxic multinodular thyroid goiter, and fibrocystic breast disease, can occur. BRRS is a congenital disorder characterized by GI hamartomatous polyposis, 
macrocephaly, developmental retardation, hemangiomas, and pigmented macules of the glans penis. The majority of the hamartomatous BRRS polyps are identified in the distal ileum and colon, though they may be seen throughout the GI tract. BRRS is not associated with an increased cancer risk.

\subsection{Adenomatous Polyposis Syndrome}

Adenomatous polyps are the most common type of polyps. Adenomatous polyposis syndrome includes familial adenomatous polyposis (FAP), hereditary nonpolyposis colon cancer (HNPCC, Lynch syndrome), and MUTYH-associated polyposis (MAP). Since polyposis is not common with Lynch syndrome, it is not included in this review.

\subsubsection{Familial Adenomatous Polyposis (FAP): Classic and Attenuated}

Familial adenomatous polyposis (FAP) is characterized by the development of hundreds to thousands of adenomatous polyps in the colorectum starting in childhood or adolescence. It is an autosomal dominant disease, caused by a germline mutation in the adenomatous polyposis coli (APC) gene (on chromosome 5q21). Without treatment, all patients will develop colorectal cancer (CRC) by the age of 40. Attenuated FAP (AFAP) is a milder form of FAP, characterized by less number of polyps $(<100)$ or later onset of adenoma and cancer. Although a smaller polyp burden, without treatment their risk of CRC is still high (80\% - 100\%).

Upper GI polyposis is common in FAP and AFAP. Gastric fundic gland polyps (FGP) are found in over 50\% of FAP patients. Although, dysplasia is reported in these lesions, FGP rarely progress to cancer. Adenomatous polyps of the duodenum and periampullary region are reported in up to 90\% of FAP cases [28]. The lifetime risk of duodenal or periampullary cancer is $4 \%-12 \%$, and is the second most common cause of cancer death in FAP patients [19] [28]. Other extraintestinal malignancies that can arise in patients with FAP include follicular or papillary thyroid cancer, hepatoblastoma, and brain tumors (mostly medulloblastomas). Turcot syndrome is a phenotypic variant of FAP, characterized by colonic polyposis along with central nervous system tumors (medulloblastoma).

Extra-intestinal manifestations associated with FAP include desmoid tumors, fibromas, epidermal cysts, osteomas (painless bony growth, most commonly on the skull and the mandible), and dental abnormalities (unerupted teeth, supernumerary teeth etc). Gardner first described these extra-intestinal lesions, and this phenotypic variant of FAP was later named as "Gardner syndrome”. While the benign growths are usually of little concern, desmoid tumors can be associated with significant morbidity and mortality, especially intraabdominal desmoids which can cause bowel obstruction, perforation, or intestinal hemorrhage. In some patients, benign pigmented lesions can be seen in the retina, known as congenital hypertrophy of the retinal pigment epithelium (CHRPE). It is not specific for FAP, but when multiple bilateral lesions are present, it should prompt for screening for FAP.

\subsubsection{MUTYH-Associated Polyposis (MAP)}

MUTYH-associated polyposis (MAP) is currently the only known autosomal recessive polyposis syndrome, caused by biallelic MUTYH mutation. Patients usually develop 10 - 100 adenomatous polyps and are typically diagnosed at 40 - 60 years of age. These colonic phenotypic features resemble AFAP [29]. However, genetic testing can be used to distinguish MAP from AFAP. Adenomatous polyps predominate in MAP, although hyperplastic polyps can be seen. Patients have a lifetime risk of $80 \%$ for CRC in biallelic mutation carriers [19], with a propensity for proximal colonic neoplasms.

Extra-colonic features include gastric fundic gland polyps, gastric and duodenal adenomas, duodenal carcinoma, carcinoid tumors, osteomas, CHRPE and Muir-Torre phenotype with sebaceous gland tumors. The extra-intestinal cancer risk is substantial in MAP, with increased risk of breast, ovarian, bladder, and skin cancer.

\subsection{Hyperplastic Polyposis}

Hyperplastic polyps (HP) are the most common non-neoplastic type of colonic polyps. They are usually diminutive (typically $<5 \mathrm{~mm}$ ) and commonly found in rectosigmoid. Histologically, they have serrated or "sawtooth" gland outlines of elongated crypts. Hyperplastic polyposis syndrome (HPS) refers to a rare, sporadic entity, in which hyperplastic polyps are found in abundance throughout the colon, with the sparing of stomach or small bowel. It is often diagnosed over 40 years of age, and no germline mutation has been identified. In contrast to 
the sporadic, small, distal hyperplastic polyps, HPS is characterized by its multiplicity, increased size and extensive distribution of polyps in the colon. The World Health Organization defined HPS as: 1) more than 5 hyperplastic polyps proximal to the sigmoid, of which 2 or more are $>1 \mathrm{~cm} ; 2$ ) any number of hyperplastic polyps proximal to the sigmoid in a patient who has a first degree relative with HPS; or 3) >30 hyperplastic polyps of any size scattered throughout the colon. HP has traditionally been considered to have no malignant potential. However, molecular studies have identified high levels of DNA methylation in some hyperplastic polyps. These can show genetic instability and be associated with Microsatellite Instability-high (MSI-H) cancers [30] [31]. This affects particularly the proximal colon, with predilection for right-sided colon cancer.

\subsection{Inflammatory Polyposis}

Inflammatory polyps are usually associated with inflammatory bowel disease (IBD) such as Crohn's disease or Ulcerative Colitis. However, there is a particular form of "inflammatory polyposis" that is not associated with IBD, and is called inflammatory "cap" polyposis (ICP). It is a rare nonneoplastic sporadic polyposis, usually limited to the large intestines, especially rectosigmoid colon, although they can progress proximally throughout the colon. The pathogenesis is unclear, but thought to be related to colonic dysmotility or recurrent mucosal trauma due to chronic straining. The common presentations are rectal bleeding, mucous diarrhea, or tenesmus. The number of polyps can vary from 1 to over 100 [32]. They are sessile or semipedunculated. The surface appears friable, erythematous, or eroded, with a white cap of fibrinopurulent exudate. Histologically, it consists of elongated, hyperplastic crypts, with inflammatory infiltrate and fibromuscular obliteration of the lamina propria [33]. Extraintestinal manifestations are absent. It is not considered a premalignant condition, and no neoplasia has so far been reported in association with ICP.

\section{Conflict of Interest}

I declare there are no conflicts of interest.

\section{References}

[1] Cronkhite, L.W. and Canada, W.J. (1955) Generalized Gastrointestinal Polyposis; an Unusual Syndrome of Polyposis, Pigmentation, Alopecia and Onychotropia. The New England Journal of Medicine, 252, 1011-1015. http://dx.doi.org/10.1056/NEJM195506162522401

[2] Ward, E.M. and Wolfsen, H.C. (2002) Review Article: The Non-Inherited Gastrointestinal Polyposis Syndromes. Alimentary Pharmacology Therapeutics, 16, 333-342. http://dx.doi.org/10.1046/j.1365-2036.2002.01172.x

[3] Daniel, E.S., Ludwig, S.L., Lewin, K.J., Ruprecht, R.M., Rajacich, G.M. and Schwabe, A.D. (1982) The Cronkhite-Canada Syndrome: An Analysis of Clinical and Pathologic Features and Therapy in 55 Patients. Medicine, 61, 293-309.

[4] Goto, A. (1995) Cronkhite-Canada Syndrome: Epidemiological Study of 110 Cases Reported in Japan. GekaHokan, 64, 3-14.

[5] Sweetser, S., Ahlquist, D.A., Osborn, N.K., Sanderson, S.O., Smyrk, T.C., Chari, S.T. and Boardman, L.A. (2012) Clinicopathologic Features and Treatment Outcomes in Cronkhite-Canada Syndrome: Support for Autoimmunity. Digestive Diseases and Sciences, 57, 496-502. http://dx.doi.org/10.1007/s10620-011-1874-9

[6] Riegert-Johnson, D.L., Osborn, N., Smyrk, T. and Boardman, L.A. (2007) Cronkhite-Canada Syndrome Hamartomatous Polyps Are Infiltrated with IgG4 Plasma Cells. Digestion, 75, 96-97. http://dx.doi.org/10.1159/000102963

[7] Takeuchi, Y., Yoshikawa, M., Tsukamoto, N., Shiroi, A., Hoshida, Y., Enomoto, Y., Kimura, T. and Fukui, H. (2003) Cronkhite-Canada Syndrome with Colon Cancer, Portal Thrombosis, High Titer of Anti-Nuclearantibodies, and Membranous Glomerulonephritis. Journal of Gastroenterology, 38, 791-795. http://dx.doi.org/10.1007/s00535-002-1148-6

[8] Patil, V., Patil, L.S., Jakareddy, R., Verma, A. and Gupta, A.B. (2013) Cronkhite-Canada Syndrome: A Report of Two Familial Cases. Indian Journal of Gastroenterology, 32, 119-122. http://dx.doi.org/10.1007/s12664-012-0296-8

[9] Kato, K., Ishii, Y., Mazaki, T., Uehara, T., Nakamura, H. and Tanaka, M. (2013) Spontaneous Regression of Polyposis Following Abdominal Colectomy and Helicobacter pylori Eradication for Cronkhite-Canada Sydrome. Case Reports in Gastroenterology, 7, 140-146. http://dx.doi.org/10.1159/000350321

[10] Okamoto, K., Isomoto, H., Shikuwa, S., Nishiyama, H., Ito, M. and Kohno, S. (2008) A Case of Cronkhite-Canada Syndrome: Remission after Treatment with Anti-Helicobacter pylori Regimen. Digestion, 78, 82-87. http://dx.doi.org/10.1159/000165354 
[11] Isobe, T., Kobayashi, T., Hashimoto, K., Kizaki, J., Miyagi, M., Aoyagi, K., Koufuji, K. and Shirouzu, K. (2013) Cronkhite-Canada Syndrome Complicated with Multiple Gastric Cancers and Multiple Colon Adenomas. American Journal of Case Reports, 14, 120-128. http://dx.doi.org/10.12659/AJCR.889083

[12] Jain, A., Nanda, S., Chakraborty, P., Kundra, A., Anuradha, S., Reddy, B.S. and Kar, P. (2003) Cronkhite-Canada Syndrome with Adenomatous and Carcinomatous Transformation of Colonic Polyp. Indian Journal of Gastroenterology, 22, 189-190.

[13] Malhotra, R. and Sheffield, A. (1988) Cronkhite-Canada Syndrome Associated with Colon Carcinoma and Adenomatous Changes in C-C Polyps. The American Journal of Gastroenterology, 83, 772-776.

[14] Nagata, J., Kijima, H., Hasumi, K., Suzuki, T., Shirai, T. and Mine, T. (2003) Adenocarcinoma and Multiple Adenomas of the Large Intestine, Associated with Cronkhite-Canada Syndrome. Digestive and Liver Disease, 35, 434-438. http://dx.doi.org/10.1016/S1590-8658(03)00160-9

[15] Ward, E.M. and Wolfsen, H.C. (2003) Pharmacological Management of Cronkhite-Canada Syndrome. Expert Opinion on Pharmacotherapy, 4, 385-389. http://dx.doi.org/10.1517/14656566.4.3.385

[16] Aretz, S. (2010) The Differential Diagnosis and Surveillance of Hereditary Gastrointestinal Polyposis Syndromes. Deutsches Arzteblatt International, 107, 163-173.

[17] Seshadri, D., Karagiorgos, N. and Hyser, M.J. (2012) A Case of Cronkhite-Canada Syndrome and a Review of Gastrointestinal Polyposis Syndromes. Gastroenterology \& Hepatology, 8, 197-201.

[18] Shah, N.B. and Lindor, N.M. (2010) Lower Gastrointestinal Tract Cancer Predisposition Syndromes. Hematology/ Oncology Clinics of North America, 24, 1229-1252. http://dx.doi.org/10.1016/j.hoc.2010.08.012

[19] Kastrinos, F. and Syngal, S. (2011) Inherited Colorectal Cancer Syndrome. Cancer Journal, 17, 405-415. http://dx.doi.org/10.1097/PPO.0b013e318237e408

[20] Brosens, L.A., Langeveld, D., van Hattem, W.A., Giardiello, F.M. and Offerhaus, G.J. (2011) Juvenile Polyposis Syndrome. World Journal of Gastroenterology, 17, 4839-4844. http://dx.doi.org/10.3748/wjg.v17.i44.4839

[21] Zbuk, K.M. and Eng, C. (2007) Hamartomatous Polyposis Syndrome. Nature Clinical Practice. Gastroenterology \& Hepatology, 4, 492-502.

[22] Howe, J.R., Mitros, F.A. and Summers, R.W. (1998) The Risk of Gastrointestinal Carcinoma in Familial Juvenile Polyposis. Annals of Surgical Oncology, 5, 751-756. http://dx.doi.org/10.1007/BF02303487

[23] Calva, D. and Howe, J.R. (2008) Hamartomatous Polyposis Syndrome. Surgical Clinics of North America, 88, $779-817$. http://dx.doi.org/10.1016/j.suc.2008.05.002

[24] Brosens, L.A., van Hattem, A., Hylind, L.M., Iacobuzio-Donahue, C., Romans, K.E., Axilbund, J., Giardiello, F.M., et al. (2007) Risk of Colorectal Cancer in Juvenile Polyposis. Gut, 56, 965-967. http://dx.doi.org/10.1136/gut.2006.116913

[25] Gammon, A., Jasperson, K., Kohlmann, W. and Burt, R.W. (2009) Hamartomatous Polyposis Syndromes. Best Practice \& Research Clinical Gastroenterology, 23, 219-231. http://dx.doi.org/10.1016/j.bpg.2009.02.007

[26] Jass, J.R. (2008) Colorectal Polyposes: From Phenotype to Diagnosis. Pathology-Research and Practice, 204, $431-447$. http://dx.doi.org/10.1016/j.prp.2008.03.008

[27] Schreibman, I.R., Baker, M., Amos, C. and McGarrity, T.J. (2005) The Hamartomatous Polyposis Syndromes: A Clinical and Molecular Review. The American Journal of Gastroenterology, 100, 476-490. http://dx.doi.org/10.1111/j.1572-0241.2005.40237.x

[28] Bülow, S., Björk, J., Christensen, I.J., Fausa, O., Järvinen, H., Moesgaard, F. and Vasen, H.F.A., DAF Study Group (2004) Duodenal Adenomatosis in Familial Adenomatous Polyposis. Gut, 53, 381-386. http://dx.doi.org/10.1136/gut.2003.027771

[29] Omundsen, M. and Lam, F.F. (2012) The Other Colonic Polyposis Syndromes. ANZ Journal of Surgery, 82, 675-681. http://dx.doi.org/10.1111/j.1445-2197.2012.06140.x

[30] Wynter, C.V., Walsh, M.D., Higuchi, T., Leggett, B.A., Young, J. and Jass, J.R. (2004) Methylation Patterns Define Two Types of Hyperplastic Polyp Associated with Colorectal Cancer. Gut, 53, 573-580. http://dx.doi.org/10.1136/gut.2003.030841

[31] Jass, J.R. (2004) Hyperplastic Polyps and Colorectal Cancer: Is There a Link? Clinical Gastroenterology and Hepatology, 2, 1-8. http://dx.doi.org/10.1016/S1542-3565(03)00284-2

[32] Ng, K.H., Mathur, P., Kumarasinghe, M.P., Eu, K.W. and Seow-Choen, F. (2004) Cap Polyposis: Further Experience and Review. Diseases of the Colon \& Rectum, 47, 1208-1215. http://dx.doi.org/10.1007/s10350-004-0561-8

[33] Petris, G.D., Dhungel, B.M., Chen, L. and Pasha, S.F. (2013) Inflammatory “Cap” Polyposis: A Case Report of a Rare Nonneoplastic Colonic Polyposis. International Journal of Surgical Pathology, 22, 378-382.

http://dx.doi.org/10.1177/1066896913501383 
Scientific Research Publishing (SCIRP) is one of the largest Open Access journal publishers. It is currently publishing more than 200 open access, online, peer-reviewed journals covering a wide range of academic disciplines. SCIRP serves the worldwide academic communities and contributes to the progress and application of science with its publication.

Other selected journals from SCIRP are listed as below. Submit your manuscript to us via either submit@scirp.org or Online Submission Portal.
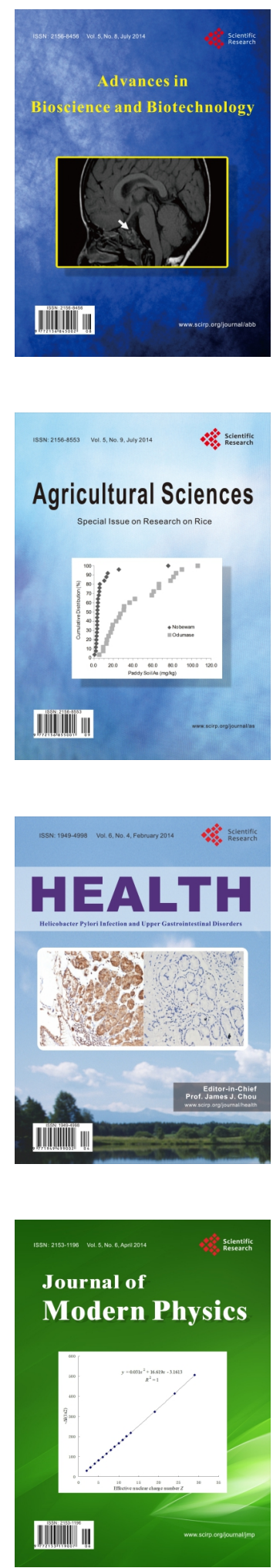
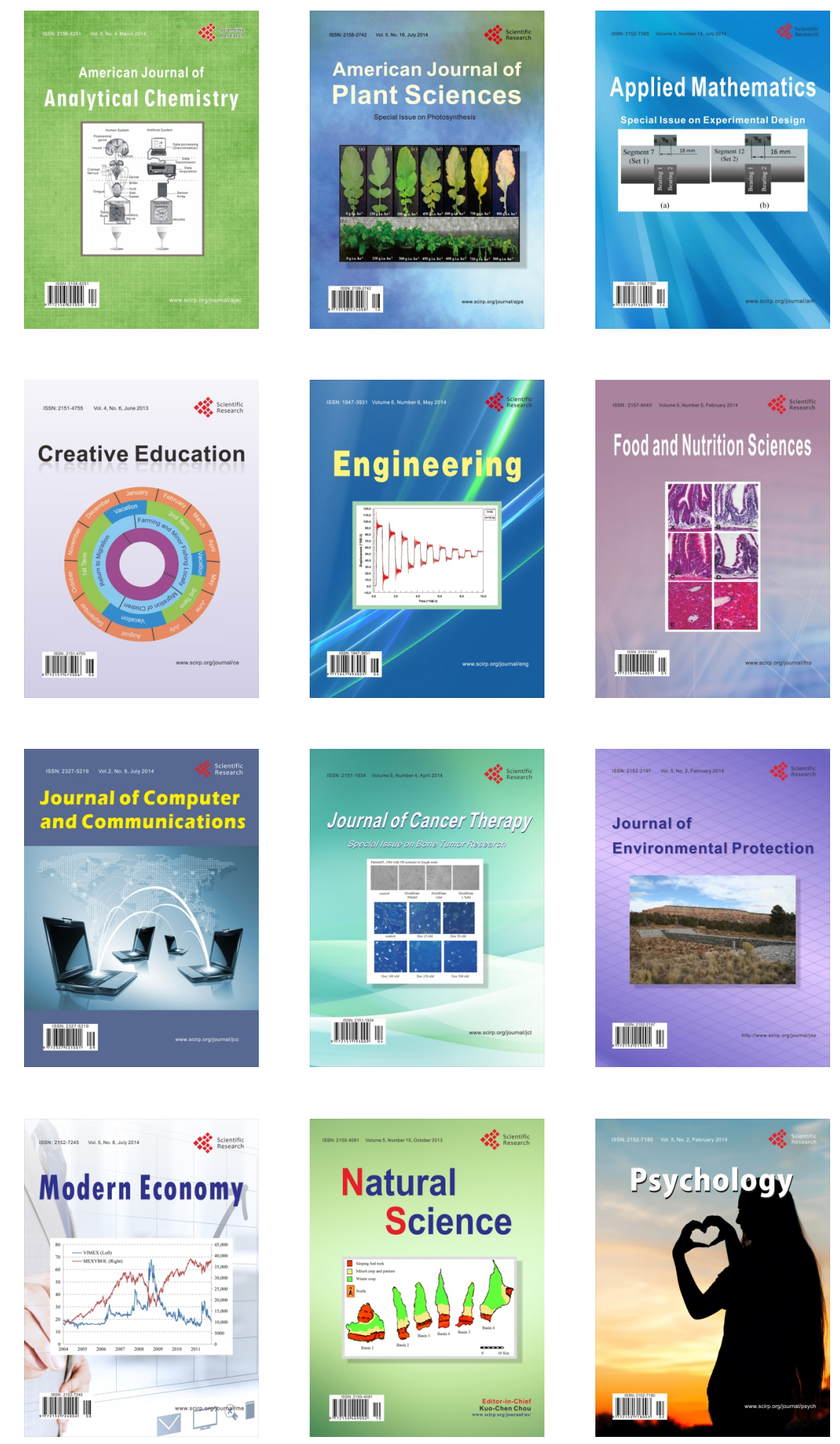